F. Reprod. Fert. (1972) 28, 87-89

\title{
LACK OF OESTROGENIC EFFECT OF o,p'-DDT ON THE IMPLANTATION OF RAT BLASTOCYSTS
}

\author{
A. Van TIENHOVEN and R. T. DUBY \\ Department of Poultry Science, Cornell University, Ithaca, N.Y., and \\ Department of Veterinary and Animal Science, University of Massachusetts, \\ Amherst, Mass.
}

(Received 4th May 1971, accepted 16th August 1971)

According to a number of reports, the administration of o, $\mathrm{p}^{\prime}$-DDT produces effects which mimic those of oestrogens in causing increases in chicken, Gallus domesticus, and quail, Coturnix coturnix japonica, oviduct weight and the uterine weight of immature and ovariectomized rats (Bitman, Cecil, Harris \& Fries, 1968; Levin, Welch \& Conney, 1968; Duby, Travis \& Terrill, 1971). The glycogen content of these organs is also increased as the result of $o, p^{\prime}-\mathrm{DDT}$ injections (Bitman et al., 1968), while the age of vaginal opening in rats is decreased (Wrenn, Wood, Fries \& Bitman, 1970). These results might be explained on the basis of an interference of $\mathrm{o}, \mathrm{p}^{\prime}$-DDT with endogenous oestrogen metabolism (Kupfer, 1967, 1969). However, in ovariectomized rats, $o, p^{\prime}-D D T$ increased the uterine weight and also inhibited the uptake of $\left[6,7-{ }^{3} \mathrm{H}\right]$ oestradiol by the uteri, suggesting a competition between the insecticide and the hormone for binding sites (Levin et al., 1968; Duby et al., 1971).

We report here the results of experiments designed to investigate whether $o, p^{\prime}$-DDT mimics the effect of oestrogens in causing implantation of blastocysts in medroxyprogesterone-treated rats or in affecting implantation in recently mated rats.

In all experiments, adult albino rats were used and were allowed free access to rat and mouse pellets. They were housed in individual cages in an airconditioned room $\left(22 \pm 2^{\circ} \mathrm{C}\right)$ with lights on from 06.00 hours to 20.00 hours. In Exps a and b, Wistar rats and, in Exp. c, a randomly bred group of rats, were used. Each female was placed with a vigorous male (in the male's cage) until a vaginal plug was found. She was then returned to her own cage. For the next 10 days, the female received daily subcutaneous (s.c.) injections of $5 \mathrm{mg}$ medroxyprogesterone-acetate (Upjohn) in $1 \mathrm{ml}$ sesame oil to prevent oestrogen secretion and ensuing implantation (Mayer \& Duluc, 1968). The treatments given on Day 11 are listed in Table 1.

The method of Yoshinaga (1961) was used to apply the oil with or without the dissolved chemicals to the uterine horns. All applications were made between 08.00 and 09.00 hours.

In all experiments, rats were assigned at random to the cages. The experiments were designed as randomized complete blocks in which each block consisted of the appropriate number of females mated to the same male. 
The rats were killed on Day 5 or 6 after the injections of DDT, oestradiol or oil, and the number of embryos was counted.

Oestrogen injections into adult mated female rats affect transport of the ova through the Fallopian tubes (Greenwald, 1967) and thus interfere with implantation of blastocysts. An experiment was carried out to determine whether

\section{TABLE 1}

EFFEGT OF $0, \mathrm{p}^{\prime}$-DDT AND OESTRADIOL-17 $\beta$ ON IMPLANTATION OF ADULT MATED FEMALE RATS TREATED WITH 5 MG MEDROXYPROGESTERONE ACETATE FOR 10 DAYS AFTER COPULATION

\begin{tabular}{|c|c|c|c|c|}
\hline Experiment & $\begin{array}{l}\text { Treatment on Day } 11 \\
\text { after copulation }\end{array}$ & $\begin{array}{l}\text { No. of } \\
\text { rats }\end{array}$ & $\begin{array}{l}\text { No. of } \\
\text { rats } \\
\text { pregnant }\end{array}$ & $\begin{array}{l}\text { Av. no. } \\
\text { of embryos } \\
\text { in pregnant } \\
\text { rats }\end{array}$ \\
\hline $\mathbf{a}$ & $\begin{array}{l}0.2 \mathrm{ml} \text { sesame oil (s.c.) } \\
0.1 \mu \mathrm{g} \text { oestradiol-17 } \beta^{*} \text { (s.c.) } \\
1 \mu \mathrm{g} \text { o,p'-DDT } \text { p }^{\prime} \text { (s.c.) }\end{array}$ & $\begin{array}{l}4 \\
4 \\
6\end{array}$ & $\begin{array}{l}0 \\
3 \\
0\end{array}$ & $\underline{\overline{12}}$ \\
\hline b & 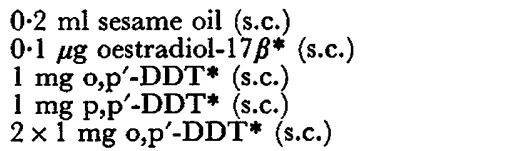 & $\begin{array}{l}6 \\
5 \\
6 \\
6 \\
5\end{array}$ & $\begin{array}{l}1 \\
3 \\
1 \\
0 \\
0\end{array}$ & $\begin{array}{l}10 \\
10 \\
18 \\
-\end{array}$ \\
\hline c & $\begin{array}{l}1 \mu \mathrm{l} \text { sesame oil into left uterine horn } \\
1 \mu \mathrm{g} \text { o, } \mathrm{p}^{\prime}-\mathrm{DDT} \dagger \text { into right uterine horn } \\
100 \mu \mathrm{g} \mathrm{p}, \mathrm{p}^{\prime}-\mathrm{DDT}+\text { into right uterine horn } \\
0.01 \mu \mathrm{g} \text { oestradiol-17 } \beta \dagger \text { into right horn } \\
1 \mu \mathrm{l} \text { sesame oil into right horn }\end{array}$ & $\begin{array}{r}22 \\
8 \\
6 \\
5 \\
3\end{array}$ & $\begin{array}{l}2 \ddagger \\
1 \neq \\
1 \neq \\
3 \\
0\end{array}$ & $\begin{array}{l}5 \cdot 5 \\
9 \\
6 \\
2 \cdot 6 \\
-\end{array}$ \\
\hline
\end{tabular}

* In $0.2 \mathrm{ml}$ sesame oil.

+ In $1 \mu$ l sesame oil.

$\mp$ In these rats, embryos were found in both horns suggesting that the medroxyprogesterone had not been effective. In the oestradiol-17 $\beta$-treated rats, no embryos were found in the control horns.

TABLE 2

NUMBER OF IMPLANTATION SITES AND OVARIAN WEIGHTS IN RATS AT DAY 10 OF PREGNANGY FOLLOWING INTRAPERITONEAL INJEGTIONS OF DDT ON DAYS 1,2 AND 3 POST COITUM

\begin{tabular}{l|c|c|c|c|c}
\hline & $\begin{array}{c}\text { Sesame } \\
\text { oil }\end{array}$ & $\begin{array}{c}\mathrm{p}, \mathrm{p}^{\prime}-D D T \\
90 \mu g\end{array}$ & $\begin{array}{c}\mathrm{p}, \mathrm{p}^{\prime}-D D T \\
900 \mu g\end{array}$ & $\begin{array}{c}\text { o, } \mathrm{p}^{\prime}-D D T \\
90 \mu g\end{array}$ & $\begin{array}{c}\text { o, } \mathrm{p}^{\prime}-D D T \\
900 \mu g\end{array}$ \\
\hline No. of animals bred & 10 & 9 & 9 & 8 & 9 \\
No. of animals pregnant & 9 & 9 & 9 & 7 & 8 \\
Ovarian weight (mg) & $65 \cdot 7$ & $62 \cdot 1$ & $57 \cdot 9$ & $61 \cdot 3$ & $72 \cdot 7$ \\
& $(2 \cdot 7)^{*}$ & $(2 \cdot 3)$ & $(2 \cdot 4)$ & $(2 \cdot 5)$ & $(3 \cdot 5)$ \\
No. of implantations & $11 \cdot 0$ & $10 \cdot 8$ & $9 \cdot 33$ & $11 \cdot 0$ & $12 \cdot 6$ \\
& $(1 \cdot 3)$ & $(0 \cdot 6)$ & $(1 \cdot 3)$ & $(1 \cdot 8)$ & $(1 \cdot 3)$ \\
\hline
\end{tabular}

* Standard error of mean, no significant differences among treatments $(P>0.05)$.

DDT would affect implantation in recently mated rats. The females were placed with the males in the evening. Vaginal smears were taken in the morning, and the day on which spermatozoa were observed in the smear was designated Day 1 of pregnancy. On Days 1, 2 or 3 of pregnancy, the animals received an injection of either 90 or $900 \mu \mathrm{g}$ o,p'-DDT or p,p'-DDT. On Day 10 of pregnancy, 
the rats were killed, the number of implantation sites counted and the ovaries were weighed. Data were analysed by analysis of variance and Duncan's New Multiple Range Test for unequal subclass numbers (Steel \& Torrie, 1960).

The results presented in Table 1 show that s.c. oestradiol injections or local applications of oestradiol will cause implantation in medroxyprogesteronetreated rats. However, neither $\mathrm{o}, \mathrm{p}^{\prime}$-DDT nor $\mathrm{p}, \mathrm{p}^{\prime}$-DDT induced implantation under these conditions.

Table 2 summarizes the results obtained in the experiment in which pregnant rats were injected with DDT on Days 1, 2 and 3 of pregnancy. These results show that neither $\mathrm{p}, \mathrm{p}^{\prime}-\mathrm{DDT}$ nor $\mathrm{o}, \mathrm{p}^{\prime}-\mathrm{DDT}$ interfered with the incidence of implantations. Oestrone, even in small doses of $20 \mu \mathrm{g}$, will reduce the litter size of rats or completely inhibit pregnancy (Duby, 1965).

From these experiments, it appears that the so-called oestrogenic effect of $o, p^{\prime}-\mathrm{DDT}$ does not extend to all actions of oestrogens in the rat. It remains to be investigated what other effects oestrogens and o,p'-DDT share, beside the effects on uterine weight and uterine glycogen concentration.

We thank Dr F. R. Frank of the Upjohn Company, Kalamazoo, Michigan, for the generous gift of medroxyprogesterone acetate.

\section{REFERENCES}

Bitman, J., Cecil, H. C., Harris, S. J. \& Fries, G. F. (1968) Estrogenic activity of o,p'-DDT in the mammalian uterus and avian oviduct. Science, N. $\Upsilon$. 162, 371.

DuBy, R. T. (1965) The effects of estrogens on pregnancy in the albino rat. M.S. thesis, University of Massachusetts, Amherst, Mass., U.S.A.

Duby, R. T., Travis, H. F. \& TERRILL, G. E. (1971) Uterotrophic activity of DDT in rats and mink and its influence on reproduction in the rat. Toxicol. appl. Pharmacol. 18, 348.

Grennwald, G. S. (1967) Species differences in egg transport in response to exogenous estrogen. Anat. Rec. 157, 163.

KUPFER, D. (1967) Effects of some pesticides and related compounds on steroid function and metabolism. Residue Rev. 19, 11.

KUPFER, D. (1969) Influence of chlorinated hydrocarbons and organophosphate insecticides on metabolism of steroids. Ann. N.Y. Acad. Sci. 160, 244.

Levin, W., Welch, R. M. \& ConNey, A. H. (1968) Estrogenic action of DDT and its analogs. Fedn Proc. Fedn Am. Socs. exp. Biol. 27, 649.

MAYeR, G. \& Duluc, A. J. (1968) Action de l'acétate de médroxyprogestérone sur la nidation. Archs Anat. Histol. Embryol. 51, 437.

Steel, R. G. D. \& Torrie, J. H. (1960) Principles and procedures of statistics, pp. 95-195. McGraw-Hill, New York.

Wrenn, T. R., Wood, J. R., Fries, G. F. \& Brtman, J. (1970) Tests of estrogenicity in rats fed low levels of o,p'-DDT. Bull. env. contam. Toxicol. (U.S.), 5, 61 .

YoshinaGA, K. (1961) Effect of local application of ovarian hormones on the delay in implantation in lactating rats. 7. Reprod. Fert. 2, 35. 